\title{
Importance of measuring testosterone in enzyme-inhibited plasma for oral testosterone undecanoate androgen replacement therapy clinical trials
}

\begin{abstract}
Aim: Testosterone undecanoate (TU) is metabolized by nonspecific esterases in blood to testosterone $(T)$. Typical clinical practice has been to analyze testosterone in human serum. The degradation of TU to testosterone was evaluated in conditions typically used in clinical studies. Methods \& Results: Freshly collected whole blood was fortified with TU at known concentration. Serum was prepared and T concentration was determined by LC-MS/MS. It was observed that TU degrades extensively to $\mathrm{T}$ in human blood under conditions typical of harvesting serum causing overestimation of $\mathrm{T}$ concentration of up to $243 \%$. These results were confirmed in a clinical study in which serum and plasma samples were compared. Conclusion: It was demonstrated that T must be analyzed in enzyme-inhibited plasma when TU is the administered medication.
\end{abstract}

Testosterone undecanoate (TU) is metabolized into testosterone. Its degradation in whole blood into testosterone was studied in conditions typically used in clinical trials. It was observed that TU degrades extensively to testosterone in human blood under conditions typical of harvesting serum, causing overestimation of testosterone concentration. It was demonstrated that testosterone must be analyzed in enzyme-inhibited plasma when TU is the administered medication. Using serum for testosterone quantitation in a clinical trial for androgen replacement therapy would bias the conclusions on formulations adjustment and use.

Keywords: enzyme inhibitor $\bullet$ hydrolysis $\bullet$ method validation $\bullet$ testosterone

- testosterone undecanoate

Testosterone undecanoate (TU), a prodrug of testosterone $(\mathrm{T})$ is metabolized by nonspecific esterases in blood to testosterone $[1,2]$. More specifically, TU is metabolized partly in the intestinal wall into 5-alpha-dihydrotestosterone undecanoate (DHTU). In blood and tissues, TU is hydrolyzed to testosterone and DHTU to dihydrotestosterone (DHT) (Figure 1). Two intramuscular (IM) and one oral testosterone replacement therapy (TRT) products using TU have been approved in the USA (IM; Aveed $^{\circledR}$ ), Europe (oral; Andriol ${ }^{\circledR}$ or Restandol ${ }^{\circledR}$ Testocaps $^{\mathrm{TM}}$; IM, Nebido ${ }^{\circledR}$ ), Canada (oral; Andriol ${ }^{\circledR}$ ) and many other countries.

Typical practice in the bioanalytical industry has been to analyze T and DHT in human serum [3-7]. To minimize conversion of TU to testosterone during the preparation of serum from blood, published literature in preclinical studies of TU has reported the use of potassium fluoride in sample collection tubes [8]. However, published clinical data on TU have used standard serum tubes without an esterase inhibitor $[2-7]$. One publication on the validation of a bioanalytical method for testosterone analysis concluded that $\mathrm{TU}$ is stable in blood [9]. Other methods developed to measure testosterone in plasma samples were published during the last decades [10,11]; however, even if these methods gave acceptable performance, they were not developed using enzymatic inhibitors and did not
Sylvain Lachance*,1, Om Dhingra², James Bernstein'2, Stéphanie Gagnon', Caroline Savard', Nathalie Pelletier', Nadine Boudreau' \& Ann Lévesque ${ }^{1}$ 'inVentiv Health clinical, Québec, Canada 2SOV Therapeutics, Morrisville, NC, USA *Author for correspondence: sylvain.lachance@inventivhealth.com

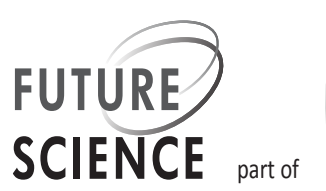




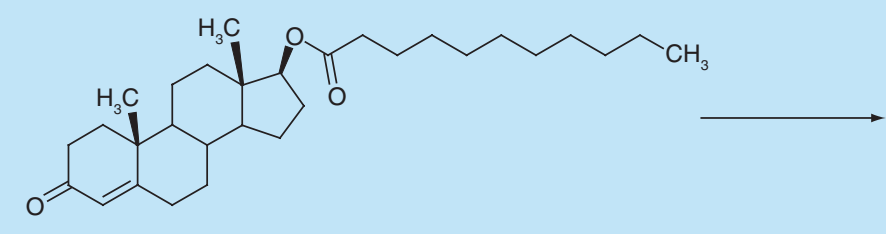

Testosterone undecanoate MW: $456.70 \mathrm{~g} / \mathrm{mol}$

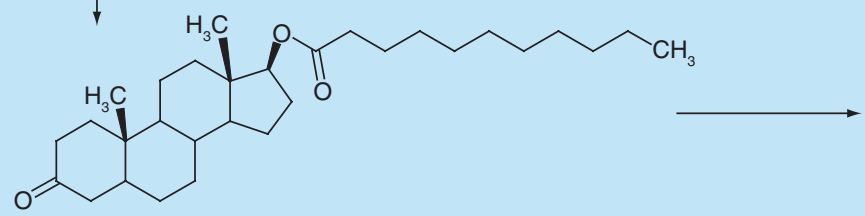

Dihydrotestosterone undecanoate MW: $458.72 \mathrm{~g} / \mathrm{mol}$

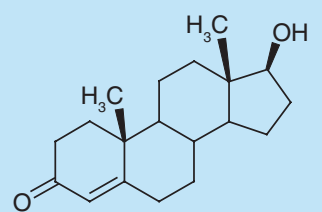

Testosterone MW: $288.42 \mathrm{~g} / \mathrm{mol}$

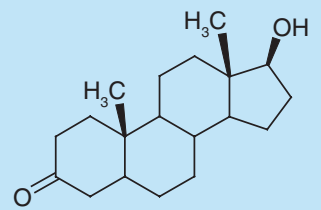

Dihydrotestosterone MW: $290.44 \mathrm{~g} / \mathrm{mol}$

Figure 1. Molecular structures of testosterone undecanoate, dihydrotestosterone undecanoate, testosterone and dihydrotestosterone.

avoid the potential conversion of the TU and DHTU into testosterone and DHT.

As part of the development and validation procedure for a bioanalytical method, the stability of the analyte in the sample should be demonstrated from the blood drawn into a collection tube through the separation of the plasma/serum from the red blood cells and other blood components. In the case of TU, we have to demonstrate that the ester does not undergo hydrolysis into $\mathrm{T}$ during sample processing. The TU concentration is sometimes more than 20- to 30-times higher than the testosterone concentration in serum or plasma [12], and therefore even minimal degradation of TU impacts the measured concentration of $\mathrm{T}$.

During investigation on the stability of TU in whole blood as a sample matrix, it was observed that TU converts rapidly into $T$. The rate of conversion was rapid and was dependent on the TU concentration. Experiments were performed to demonstrate the instability of TU and its impact on T concentration. The potential conversion of the metabolite dihydrotestosterone undecanoate (DHTU) to DHT is also discussed. Data are also presented on the best choice of sample matrix and collection tube for clinical measurement of $T$ when $\mathrm{TU}$ is administered. The impact of the TU conversion on the $T$ concentration could lead to inappropriate decisions on the starting dose and dose adjustments for patients on TU containing TRT products.

\section{Materials \& methods}

Four validated methods were used for the present work for the collection and processing of samples: testoster- one and DHT in serum tubes, testosterone and DHT in sodium fluoride/potassium oxalate $\left(\mathrm{NaF} / \mathrm{K}_{2} \mathrm{C}_{2} \mathrm{O}_{4}\right)$ plasma tubes, testosterone and DHT in sodium fluoride/sodium ethylenediaminetetraacetate $\left(\mathrm{NaF} / \mathrm{Na}_{2}\right.$ EDTA) plasma tubes and TU and DHTU in $\mathrm{NaF} / \mathrm{Na}_{2}$ EDTA plasma tubes.

Briefly, T and DHT were extracted from the sample matrix (serum or plasma) by liquid-liquid extraction. $0.500 \mathrm{ml}$ of the deuterated internal standards working solution and the buffer solution (Trizma Base $500 \mathrm{mM}$, Sigma, Oakville, Canada) is added to $0.300 \mathrm{ml}$ of matrix. After adequate mixing, $5 \mathrm{ml}$ of extraction solvent methyl tert-butyl ether (MTBE from EMD, Toronto, Canada) was added, mixed well for $15 \mathrm{~min}$ and centrifuged at $1950 \mathrm{~g}$ for $5 \mathrm{~min}$ at room temperature. The top layer was then transferred to a borosilicate tube and evaporated to dryness. The dry residue is reconstituted with $0.150 \mathrm{ml}$ of mobile phase and injected onto the HPLC column (ACE Excel 2 C18-PFP, $100 \times 3 \mathrm{~mm}, 2 \mu \mathrm{m}$ from Life Science, Canada) using reverse phase chromatography conditions. The mobile phase is a mixture of methanol (EMD, Canada), Milli-Q Type water and acetic acid (EMD, Canada) in a proportion of 70/30/0.2. Detection was done by MS (LC-MS/MS) using the AB SCIEX API 5000 (Toronto, Canada). Positive ionization modes using the TurbolonSpray were optimized with the mass transitions $290.4 \rightarrow 97.0 \mathrm{amu}$ for testosterone, $291.3 \rightarrow 255.4$ amu for DHT, 294.4 $\rightarrow 97.0$ amu for testosterone- $\mathrm{d}_{5}$ and $294.4 \rightarrow 258.4 \mathrm{amu}$ for DHT- $\mathrm{d}_{3}$.

TU and DHTU were extracted from $0.150 \mathrm{ml}$ of matrix by an automated liquid-liquid extraction 
using $1.5 \mathrm{ml}$ of methyl tert-butyl ether and $0.200 \mathrm{ml}$ of ammonium formate $\mathrm{pH} 5$ buffer (Fluka, Oakville, Canada). Deuterated internal standards were used for both analytes. The analytes are extracted, the upper phase transferred and evaporated to dryness. The dry residue was reconstituted with the mobile phase (Milli-Q water/methanol 10/90 ammonium formate $5 \mathrm{mM}$, formic acid $0.1 \%$ ), injected onto the HPLC column (Waters BEH Phenyl, $50 \times 3 \mathrm{~mm}, 1.7 \mu \mathrm{m}$, Canada) and analyzed by LC-MS/MS using the AB SCIEX API 5000. Positive ionization modes using the TurbolonSpray were optimized with the mass transitions $457.4 \rightarrow 271.3 \mathrm{amu}$ for $\mathrm{TU}, 476.5 \rightarrow 273.3$ amu for DHTU, $462.5 \rightarrow 276.3 \mathrm{amu}$ for TU-d $\mathrm{d}_{5}$ and $497.6 \rightarrow 273.3 \mathrm{amu}$ for DHTU-d $\mathrm{d}_{21}$.

\section{Method validation for the determination of testosterone, DHT, TU \& DHTU}

The methods were validated as per the most recent US FDA and EMA validation guidelines [13,14]. During the method validation, the accuracy, precision, withinrun, between-run, selectivity, matrix effect as well as the stability (stability in whole blood at $4^{\circ} \mathrm{C}$, shortterm stability in matrix at room temperature, freezethaw stability at $-20^{\circ} \mathrm{C} /-80^{\circ} \mathrm{C}$, long-term stability at $-20^{\circ} \mathrm{C} /-80^{\circ} \mathrm{C}$ ) were evaluated.

For $\mathrm{T}$ and DHT in serum, the method was validated according to the guidelines. However, stability of the analytes in whole blood in the presence of TU and DHTU did not meet the acceptance criteria due to apparent degradation of TU and DHTU into T and DHT, respectively.

\section{Evaluation of the conversion of TU in whole blood}

During the method development and validation, the conversion of TU into testosterone or secondarily DHTU to DHT in whole blood was verified. In fresh whole blood, a quantity of TU at different concentrations was added to the matrix. These tests were performed in presence or absence of additives. If no additives were used, the aliquots were set-aside for at least $30 \mathrm{~min}$ (minimal period required for complete coagulation) at room temperature before processing to serum. The plasma or serum was separated by centrifugation and testosterone and DHT concentration was analyzed.

\section{Application of the selected assay to a clinical study}

A clinical study was performed at the inVentiv Health Clinical facilities where fifteen asymptomatic hypogonadal male subjects aged 18 to 75 years were administered an oral dose of TU twice daily for 84 consecu- tive days under fed conditions. Each volunteer was informed on the risk of procedure and risk of the clinical study by signing the informed consent. On day 84, serum and plasma samples were collected predose and at $1.5,3,4,5,6,8,10,12,13.5,15,16,17,18,20$, 22 and $24 \mathrm{~h}$ after the morning dose. One of the main objectives of this study part was to compare the levels of T and DHT measured with a validated method in $\mathrm{NaF} / \mathrm{Na}_{2}$ EDTA plasma to the levels measured in serum.

Pharmacokinetic (PK) parameters were assessed using samples collected on day 84: Ln-transformed area under the concentration-time curve $\left(\mathrm{AUC}_{0-24}\right)$ and the maximum concentration of analyte $\left(\mathrm{C}_{\max 0-24}\right)$ obtained with the study samples collected from $0-24 \mathrm{~h}$ after the morning dose of TU on last study day 84 were used to compare the levels of testosterone, DHT, TU and DHTU measured in serum in comparison to the levels measured in plasma.

\section{Experiments \& results}

\section{Evaluation of the conversion of TU in whole} blood without additives over time

TU at a concentration of $160,000 \mathrm{ng} / \mathrm{dl}$ and DHTU at a concentration of $74,000 \mathrm{ng} / \mathrm{dl}$ were added to freshly collected whole blood containing no additive and mixed. Aliquots were set aside for 30, 90 and $240 \mathrm{~min}$ at room temperature and then the serum was separated by centrifugation and analyzed.

A significant increase of the T and DHT concentrations in the samples was observed suggesting instability of TU and DHTU in the whole blood samples. Testosterone and DHT concentrations increased from 1816.9 to $6172.8 \mathrm{ng} / \mathrm{dl}$, from 176.6 to $1012.9 \mathrm{ng} / \mathrm{dl}$, respectively, when TU and DHTU was incubated in whole blood without additive from 30 to $240 \mathrm{~min}$ at room temperature (Supplementary Figure 1). It must be noted that no testosterone was added to the samples.

These results demonstrated that TU and DHTU degrade into T and DHT during the clotting period of the sample collection and serum harvesting. To improve the accuracy of T and DHT measurement, inhibition of the enzymatic degradation appears necessary.

\section{Impact of the TU concentration on T in whole blood during clotting with time}

Fresh whole blood was collected without anticoagulant from a single donor and the endogenous $T$ level was determined as $23.75 \mathrm{ng} / \mathrm{dl}$. The whole blood sample was fortified with different concentrations of TU, ranging from 1500 to $70,000 \mathrm{ng} / \mathrm{dl}$ and set aside for clotting for 30 and $60 \mathrm{~min}$. Different TU concentrations were tested in order to evaluate the potential 
impact of varying TU levels on $\mathrm{T}$ concentration during a clinical study in which TU will be administered. The clotting time were set to mimic the incubation times typically used during a clinical trial. The resulting serum was analyzed for $\mathrm{T}$ and compared with the endogenous level of $\mathrm{T}$.

Results are presented in Table 1. The concentrations of $\mathrm{T}$ increased over time and depended on the concentration of TU used to fortify the samples, showing that TU degrades rapidly into $\mathrm{T}$ in whole blood during clotting and serum harvesting. Moreover, even low concentrations of TU have an impact on testosterone concentrations.

\section{Comparison of different additives to prevent the conversion of TU to T}

Since the stability of blood samples containing TU is hypothesized to be influenced by the activity of esterases in the blood, sample collection was performed with different collection tubes (Table 2) to investigate the optimum sample collection tubes.

Fresh whole blood from one donor (subject 2) was collected in each type of tube and endogenous $T$ level was determined. Serum tubes were allowed to clot for $30 \mathrm{~min}$ at room temperature, plasma tubes were set aside for $10 \mathrm{~min}$ at $4^{\circ} \mathrm{C}$. The plasma or serum was obtained by centrifugation and analyzed for $\mathrm{T}$. Results are presented in the Table 2. It was observed that $\mathrm{NaF}$ may introduce a negative bias in the testosterone measurement as the degree of difference increases with the percent of $\mathrm{NaF}$ in the tubes. However, for whole blood collected with tubes with $\mathrm{NaF}(0.43 \%)$, this bias was less significant $(-0.7 \%)$. It is noted that the incubation temperature for this tube is room temperature as serum is to be harvested, contrary to plasma for other tubes with $\mathrm{NaF}$. As it is explained further in another section, partitioning of the analyte is suspected to be impacted by $\mathrm{NaF}$. This partitioning is likely sensitive to temperature resulting in different bias at room temperature than $4^{\circ} \mathrm{C}$.

The same collection tubes were used to evaluate the degradation of TU. Fresh whole blood from one donor (subject 1) was collected in the different collection tubes. Each sample was fortified with TU at a final concentration of $60,000 \mathrm{ng} / \mathrm{dl}$. This concentration was evaluated as the potential $\mathrm{C}_{\max }$ of TU. This recommendation is based on the ratio relationship between DHT and T levels as well as TU and DHTU levels [7]. For each tube, a comparison sample and a stability sample were prepared. For the serum tubes, one aliquot was allowed to clot for $30 \mathrm{~min}$ (comparison samples), the other for $60 \mathrm{~min}$ at room temperature (stability samples). For the RST tubes, the time was set at 10 (comparison samples) and $40 \mathrm{~min}$ (stability samples) since the clotting is very fast. $\mathrm{NaF} 0.43 \%$ tubes and RST (rapid serum tubes) were processed as the serum. For the plasma samples $\left(\mathrm{NaF} / \mathrm{Na}_{2} \mathrm{EDTA}\right.$, $\mathrm{NaF} / \mathrm{K}_{2} \mathrm{C}_{2} \mathrm{O}_{4}$, EDTA $\mathrm{K}_{2}$ and $\mathrm{BD}^{\mathrm{TM}} \mathrm{P} 800$ containing Protease and Esterase Inhibitor tubes) one aliquot was set aside for $10 \mathrm{~min}$ at $4^{\circ} \mathrm{C}$ (comparison samples) and another for $60 \mathrm{~min}$ at $4^{\circ} \mathrm{C}$ (stability samples). After the respective duration, the plasma or serum was obtained by centrifugation and analyzed for testosterone and compared. The condition of each sample and results are also presented in the Table 2. It is clear from the results that temperature has an effect on the conversion as demonstrated by the samples that were collected at room temperature. In addition, esterase inhibition with $\mathrm{NaF}$ does not completely prevent hydrolysis of $\mathrm{TU}$ to $\mathrm{T}$, but minimizes it when used along with additives (EDTA or $\mathrm{K}_{2} \mathrm{C}_{2} \mathrm{O}_{4}$ ). Considering this, three types of anticoagulants were selected for further investigation: $\mathrm{K}_{2}$ EDTA, $\mathrm{NaF} / \mathrm{Na}_{2}$ EDTA and $\mathrm{NaF} / \mathrm{K}_{2} \mathrm{C}_{2} \mathrm{O}_{4}$. It was

\begin{tabular}{|c|c|c|c|c|}
\hline $\begin{array}{l}\text { TU Concentration } \\
\text { Fortified (ng/dl) }\end{array}$ & $\begin{array}{l}\text { Duration of } \\
\text { incubation ( } \mathrm{min})\end{array}$ & $\begin{array}{l}\text { Concentration testosterone } \\
\text { measured }(\mathrm{ng} / \mathrm{dl})\end{array}$ & $\begin{array}{l}\% \text { difference vs } \\
\text { TU }=0(\%)\end{array}$ & $\begin{array}{l}\% \text { difference } 30 \text { vs } \\
60 \min (\%)\end{array}$ \\
\hline 0 & 0 & 23.75 & - & - \\
\hline \multirow[t]{2}{*}{1500} & 30 & 36.76 & 54.8 & 24.6 \\
\hline & 60 & 45.81 & 92.9 & \\
\hline \multirow[t]{2}{*}{10,000} & 30 & 152.66 & 542.8 & 65.8 \\
\hline & 60 & 253.18 & 966.0 & \\
\hline \multirow[t]{2}{*}{30,000} & 30 & 306.02 & 1188.5 & 73.9 \\
\hline & 60 & 532.19 & 2140.8 & \\
\hline \multirow[t]{2}{*}{70,000} & 30 & 732.49 & 2984.2 & 72.4 \\
\hline & 60 & 1262.81 & 5217.1 & \\
\hline
\end{tabular}


Table 2. Conversion of testosterone undecanoate into testosterone in whole blood collected with different collection tubes and endogenous level of testosterone in different collection tubes.

\begin{tabular}{|c|c|c|c|c|c|c|c|c|c|}
\hline \multirow[t]{3}{*}{ Matrix } & \multirow[t]{3}{*}{ Anticoagulant } & \multirow{3}{*}{$\begin{array}{l}\text { Comparison } \\
\text { sample }^{\dagger}\end{array}$} & \multicolumn{7}{|c|}{ Testosterone concentration (ng/dl) } \\
\hline & & & \multicolumn{5}{|c|}{ Subject 1} & \multicolumn{2}{|c|}{ Subject 2} \\
\hline & & & $\begin{array}{l}\text { Stability } \\
\text { sample }\end{array}$ & $\begin{array}{l}\text { Comparison } \\
\text { sample }\end{array}$ & $\begin{array}{l}\text { \% change vs } \\
\text { unfortified } \\
\text { serum }\end{array}$ & $\begin{array}{l}\text { Stability } \\
\text { sample }\end{array}$ & $\begin{array}{l}\% \\
\text { change }\end{array}$ & $\begin{array}{l}\text { Endogenous } \\
\text { level }^{\ddagger}\end{array}$ & $\begin{array}{l}\text { \% change vs } \\
\text { unfortified } \\
\text { serum }\end{array}$ \\
\hline Serum & $\begin{array}{l}\text { Without } \\
\text { anticoagulant } \\
\text { not fortified }\end{array}$ & $\begin{array}{l}30 \mathrm{~min} \\
\text { at RT }\end{array}$ & NA & 370.61 & Reference & NA & NA & 287.21 & Reference \\
\hline Serum & $\begin{array}{l}\text { Without } \\
\text { anticoagulant }\end{array}$ & $\begin{array}{l}30 \mathrm{~min} \\
\text { at RT }\end{array}$ & $\begin{array}{l}60 \mathrm{~min} \\
\text { at RT }\end{array}$ & 1270.19 & 242.7 & 1967.80 & 54.9 & 282.51 & -1.6 \\
\hline Serum & $\begin{array}{l}\text { Rapid serum } \\
\text { tube without } \\
\text { anticoagulant }\end{array}$ & $\begin{array}{l}10 \mathrm{~min} \\
\text { at } \mathrm{RT}\end{array}$ & $\begin{array}{l}40 \mathrm{~min} \\
\text { at RT }\end{array}$ & 814.41 & 119.7 & 1228.29 & 50.8 & 247.77 & -13.7 \\
\hline Serum & $\mathrm{NaF} 0.43 \%$ & $\begin{array}{l}30 \mathrm{~min} \\
\text { at RT }\end{array}$ & $\begin{array}{l}60 \mathrm{~min} \\
\text { at RT }\end{array}$ & 992.38 & 167.8 & 1592.15 & 60.4 & 285.29 & -0.7 \\
\hline Plasma & 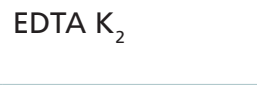 & $\begin{array}{l}10 \mathrm{~min} \\
\text { at } 4^{\circ} \mathrm{C}\end{array}$ & $\begin{array}{l}60 \mathrm{~min} \\
\text { at } 4^{\circ} \mathrm{C}\end{array}$ & 441.91 & 19.2 & 528.99 & 19.7 & 262.77 & -8.5 \\
\hline Plasma & $\begin{array}{l}\mathrm{NaF}(0.15 \%)-\mathrm{Na}_{2} \\
\text { EDTA }\end{array}$ & $\begin{array}{l}10 \mathrm{~min} \\
\text { at } 4^{\circ} \mathrm{C}\end{array}$ & $\begin{array}{l}60 \mathrm{~min} \\
\text { at } 4^{\circ} \mathrm{C}\end{array}$ & 392.77 & 6.0 & 452.53 & 15.2 & 247.89 & -13.7 \\
\hline Plasma & $\begin{array}{l}\mathrm{NaF} \\
(0.25 \%)-\mathrm{K}_{2} \mathrm{C}_{2} \mathrm{O}_{4}\end{array}$ & $\begin{array}{l}10 \mathrm{~min} \\
\text { at } 4^{\circ} \mathrm{C}\end{array}$ & $\begin{array}{l}60 \mathrm{~min} \\
\text { at } 4^{\circ} \mathrm{C}\end{array}$ & 409.15 & 10.4 & 461.07 & 12.7 & 233.78 & -18.6 \\
\hline Plasma & $\begin{array}{l}\text { BD }{ }^{\mathrm{TM}} \text { P800 } \\
\text { containing } \\
\text { protease and } \\
\text { esterase inhibitor }\end{array}$ & $\begin{array}{l}10 \mathrm{~min} \\
\text { at } 4^{\circ} \mathrm{C}\end{array}$ & $\begin{array}{l}60 \mathrm{~min} \\
\text { at } 4^{\circ} \mathrm{C}\end{array}$ & 479.57 & 29.4 & 720.30 & 50.2 & 283.29 & -1.4 \\
\hline $\begin{array}{l}\text { Samples v } \\
\text { }{ }^{\text {SSamples }} \\
\text { samples, } \\
\text { 'Endogen } \\
\text { "EDTA: Eth }\end{array}$ & $\begin{array}{l}\text { e fortified with } 60,00 \\
\text { incubated for } 30 \text { min } \\
\text { ole blood is incubated } \\
\text { level was determined } \\
\text { nediaminetetraacetate }\end{array}$ & $\begin{array}{l}\mathrm{ng} / \mathrm{dl} \text { of testoster } \\
\text { when blood is coll } \\
\text { for } 10 \text { min at } 4^{\circ} \mathrm{C} \\
\text { in matrices from a } \\
\text {; NA: Not applical }\end{array}$ & $\begin{array}{l}\text { rone undecar } \\
\text { lected to allo } \\
\text { as handled ir } \\
\text { a different do } \\
\text { ble; RT: Room }\end{array}$ & $\begin{array}{l}\text { hoate. } \\
\text { w the coagulation } \\
\text { clinic. } \\
\text { pnor than the testc } \\
\text { temperature. }\end{array}$ & $\begin{array}{l}\text { and to mimic the } \\
\text { osterone undecano }\end{array}$ & $\begin{array}{l}\text { clinical sam } \\
\text { ate convers }\end{array}$ & $\begin{array}{l}\text { nandling } \\
\text { tests. }\end{array}$ & erum samples a & d for plasma \\
\hline
\end{tabular}

found that EDTA alone did not prevent conversion of TU to $\mathrm{T}$, and that $\mathrm{NaF} / \mathrm{K}_{2} \mathrm{C}_{2} \mathrm{O}_{4}$ and $\mathrm{NaF} / \mathrm{Na}_{2}$ EDTA were equivalent (see Supplementary Tables 1 \& 2).

Comparison of testosterone levels in serum of different donors in plasma with $\mathrm{NaF} / \mathrm{Na}_{2}$ EDTA \& $\mathrm{NaF} / \mathrm{K}_{2} \mathrm{C}_{2} \mathrm{O}_{4}$

Since testosterone is usually analyzed in the serum in the biomedical laboratories, it is preferable to identify anticoagulants that can give endogenous $\mathrm{T}$ concentration in plasma equivalent to the serum. A comparison of the endogenous level of testosterone for eight different donors was done in serum, $\mathrm{NaF} / \mathrm{Na}_{2}$ EDTA plasma and $\mathrm{NaF}$ / $\mathrm{K}_{2} \mathrm{C}_{2} \mathrm{O}_{4}$ plasma. As the method was intended for clinical trials applications, eight different donors were tested. Results are presented in Table 3. The mean percent of difference of endogenous $\mathrm{T}$ concentrations between serum and $\mathrm{NaF} / \mathrm{Na}_{2}$ EDTA plasma was 11.7 and $13.8 \%$ between $\mathrm{NaF} / \mathrm{K}_{2} \mathrm{C}_{2} \mathrm{O}_{4}$ plasma and serum. The difference in endogenous $\mathrm{T}$ concentrations measured with $\mathrm{NaF}$ / $\mathrm{Na}_{2}$ EDTA and $\mathrm{NaF} / \mathrm{K}_{2} \mathrm{C}_{2} \mathrm{O}_{4}$ tubes is not clinically sig- nificant, although there is a slight preference for $\mathrm{NaF} / \mathrm{Na}_{2}$ EDTA due to the slightly lower bias.

Wang et al. suggested that the use of $\mathrm{NaF}$ introduces a negative bias of $20 \%$ compared with serum samples [9]. A negative bias is consistent with our investigation and a mean $\%$ bias of $-11.7 \%$ (Table 3) was observed for the testosterone basal level in $\mathrm{NaF} / \mathrm{Na}_{2}$ EDTA plasma compared with human serum in normal blood donors. As the addition of $\mathrm{NaF}$ is important to minimize the hydrolysis of TU, this negative but reproducible bias is not clinically significant when compared with the uncontrolled clinically meaningful increase (i.e., about $30-35 \%)$ of testosterone concentration in the presence of TU as would occur in serum samples.

\section{Determination of endogenous level of} testosterone in whole blood $\left(\mathrm{NaF} / \mathrm{K}_{2} \mathrm{C}_{2} \mathrm{O}_{4^{\prime}}\right.$ $\mathrm{NaF} / \mathrm{Na}_{2}$ EDTA, BD ${ }^{\mathrm{TM}} \mathrm{P} 800$ containing protease \& esterase inhibitor)

It was observed in the above experiments that $\mathrm{NaF}$ (refer to Table 2) suppressed the testosterone concentra- 
Table 3. Comparison of testosterone endogenous levels between serum and plasma with $\mathrm{NaF} / \mathrm{Na}_{2}$ ethylenediaminetetraacetate and $\mathrm{NaF} / \mathrm{K}_{2} \mathrm{C}_{2} \mathrm{O}_{2}$ in different donors.

\begin{tabular}{|c|c|c|c|c|c|}
\hline Donors & $\begin{array}{l}\text { Testosterone concentration } \\
\text { in serum }(\mathrm{ng} / \mathrm{dl})\end{array}$ & $\begin{array}{l}\text { Testosterone concentration } \\
\left.\text { in } \mathrm{NaF} / \mathrm{Na}_{2} \text { EDTA ( } \mathrm{ng} / \mathrm{dl}\right)\end{array}$ & $\begin{array}{l}\% \text { change } \\
\text { vs serum }\end{array}$ & $\begin{array}{l}\text { Testosterone concentration } \\
\left.\text { in } \mathrm{NaF} / \mathrm{K}_{2} \mathrm{C}_{2} \mathrm{O}_{4} \text { ( } \mathrm{ng} / \mathrm{dl}\right)\end{array}$ & $\begin{array}{l}\% \text { change } \\
\text { vs serum }\end{array}$ \\
\hline 1 & 301.62 & 273.63 & -9.3 & 254.22 & -15.7 \\
\hline 2 & 309.23 & 273.18 & -11.7 & 280.06 & -9.4 \\
\hline 3 & 479.70 & 424.16 & -11.6 & 399.71 & -16.7 \\
\hline 4 & 555.39 & 485.15 & -12.7 & 457.20 & -17.7 \\
\hline 5 & 511.13 & 467.45 & -8.6 & 507.68 & -0.7 \\
\hline 6 & 576.13 & 487.55 & -15.4 & 483.81 & -16.0 \\
\hline 7 & 490.22 & 432.20 & -11.8 & 421.20 & -14.1 \\
\hline 8 & 263.80 & 230.30 & -12.7 & 211.26 & -19.9 \\
\hline Mean & 435.90 & 384.20 & -11.7 & 376.89 & -13.8 \\
\hline SD ( $( \pm)$ & 124.31 & 106.86 & & 112.97 & \\
\hline CV (\%) & 28.5 & 27.8 & & 30.0 & \\
\hline
\end{tabular}

tion. In order to determine if this bias is related to ion suppression or testosterone degradation in presence of $\mathrm{NaF}$, freshly collected whole blood in different tubes were analyzed. Here, tubes with additives were used to analyze testosterone in whole blood. As it was observed previously that there was no difference in endogenous level of testosterone in serum versus $\mathrm{K}_{2}$ EDTA plasma, this tube was used as a comparator. Serum and plasma of the same samples were harvested and analyzed for testosterone concentrations.

Testosterone concentrations in whole blood were compared for each anticoagulant and the results showed no significant difference between the anticoagulant tested (Supplementary Tables 3 \& 4). The harvested serum or plasma was analyzed for testosterone and the negative bias due to $\mathrm{NaF}$ was again observed. As testosterone concentration in whole blood is similar between each anticoagulant, it suggests that $\mathrm{NaF}$ does not cause ion suppression to the LC-MS/MS detection. It could also suggest that partitioning between erythrocytes and plasma is slightly different when using tubes with or without $\mathrm{NaF}$ in the tube.

In addition, quality controls were prepared in human serum and were analyzed with a calibration curve prepared in $\mathrm{NaF} / \mathrm{K}_{2} \mathrm{C}_{2} \mathrm{O}$ plasma. The mean percent of bias of the quality controls in human serum were all within $2 \%$ of the nominal concentrations, showing that the sodium fluoride does not affect the quantitation of testosterone. Results are provided in Supplementary Table 5.

Validation in human $\mathrm{NaF} / \mathrm{Na}_{2}$ EDTA \& NaF/ $/ \mathrm{K}_{2} \mathrm{C}_{2} \mathrm{O}_{4}$ plasma

Complete validations were done for plasma samples obtained from $\mathrm{NaF} / \mathrm{K}_{2} \mathrm{C}_{2} \mathrm{O}_{4}$ or $\mathrm{NaF} / \mathrm{Na}_{2}$ EDTA col- lection tubes in accordance with the most recent FDA and EMA validation guidelines [13,14]. All tests met the acceptance criteria. The equivalence between the anticoagulants $\mathrm{NaF} / \mathrm{K}_{2} \mathrm{C}_{2} \mathrm{O}_{4}$ and $\mathrm{NaF}-\mathrm{Na}_{2}$ EDTA was confirmed.

The assay for the determination of $\mathrm{T}$ and DHT in human plasma or in human serum was validated over the dynamic range of 100-30,000 and $50-5000 \mathrm{pg} / \mathrm{ml}$ for $\mathrm{T}$ and DHT, respectively. Linearity was demonstrated with coefficient of determination $\left(\mathrm{r}^{2}\right)$ higher than 0.9927 for both analytes in all batches. Accuracy (\% bias) and precision (coefficient of variation) were within 6.7 and $8.5 \%$, respectively. The extraction recovery was also determined and was higher than 85 and $83 \%$ for T and DHT, respectively.

TU and DHTU method was validated in human plasma over the dynamic range of $1-1000$ and $0.5-500 \mathrm{ng} / \mathrm{ml}$ for TU and DHTU, respectively. The coefficient of determination $\left(\mathrm{r}^{2}\right)$ was higher than 0.9935 for TU and DHTU in all validation batches. Accuracy and precision were demonstrated with\% bias within $1 \%$ and coefficient of variation within $10 \%$. The extraction recovery was of 81 and $84 \%$ for TU and DHTU, respectively.

Additional tests were done during the method validation to prove the stability of the analytes and that no other conversion occurred (e.g., glucuronide degradation) (Supplementary Tables 6 \& 7). Testosterone glucuronide had no impact on the quantitation of T and DHT when low and high T and DHT level quality controls fortified with testosterone glucuronide were submitted to stress conditions such as freeze-thaw cycles, incubation at room temperature, 
$4^{\circ} \mathrm{C}$, long-term storage at -20 or $-80^{\circ} \mathrm{C}$. The impact of the glucuronide was also assessed in whole blood during sample collection and handling.

Moreover, the possible degradation of $\mathrm{TU}$ and DHTU into T or DHT was assessed when low and high $\mathrm{T}$ and DHT level quality controls were submitted to freeze-thaw cycles, incubation at room temperature or $4^{\circ} \mathrm{C}$ and long-term storage at -20 and $-80^{\circ} \mathrm{C}$. No increase of the T and DHT concentrations were observed during these stability studies. Since the degradation was specifically observed in whole blood during sample collection, the impact of TU and DHTU was also assessed in in low- and high-quality controls prepared in whole blood and set aside for $110 \mathrm{~min}$ at $4^{\circ} \mathrm{C}$. The results obtained during validation clearly show that the use of plasma $\mathrm{NaF} / \mathrm{Na}_{2}$ EDTA is adequate for quantitation of $\mathrm{T}$ and DHT.

However, for the method in human serum, the evaluation of the degradation of TU and DHTU during sample collection in whole blood did not meet the acceptance criteria. Indeed, an increase of the $\mathrm{T}$ concentration of up to $83 \%$ was observed after $60 \mathrm{~min}$ at room temperature of clotting time compared with the regular $30 \mathrm{~min}$ while DHT concentration increased by $140 \%$.

\section{Comparison of the TU to T conversion depending on the TU spiking solvent used} Wang et al. [9] published that addition of TU to blood did not increase the measured serum $T$ levels even at high concentrations, which is not in accordance to the findings presented here. We decided to investigate further to better understand the discordance between the conclusions. Literature descriptions of sample preparations include a stock solution prepared in ethanol and diluted in phosphate buffer saline (PBS) [9]. In the experiments carried out in the study reported here, it was observed that the stock and spiking solution preparation is very important. A stock solution of TU was prepared in ethanol and diluted with PBS prior to being added to whole blood. Results from this procedure were compared with those typically used in our experiments with TU stock prepared and diluted using methanol, prior to being added to whole blood. It was observed that a precipitate occurred in the PBS solution after a freeze-thaw cycle.

To investigate this effect further, freshly collected whole blood was collected in conventional serum tubes and in $\mathrm{NaF} / \mathrm{K}_{2} \mathrm{C}_{2} \mathrm{O}_{4}$ tubes. Each whole blood tube was fortified with TU at a final concentration of $60,000 \mathrm{ng} / \mathrm{dl}$ with solution prepared either in methanol or in ethanol/PBS; each experiment was performed in triplicate. Serum samples were incubated at room temperature for 30 and $60 \mathrm{~min}$, and plasma samples were incubated for 10,30 and $60 \mathrm{~min}$ at $4^{\circ} \mathrm{C} . \mathrm{T}$ and $\mathrm{TU}$ were analyzed in the plasma and serum samples obtained.

Table 4 summarizes the results obtained. Testosterone and TU concentrations are stable when the stock and working solution of TU was prepared in methanol and plasma obtained from the whole blood sample. In contrast, the $\mathrm{T}$ and $\mathrm{TU}$ concentrations in serum samples prepared using either methanol or ethanol/PBS spiking solutions were variable. The TU concentrations for serum samples spiked using TU in methanol appears stable, but the $\mathrm{T}$ concentrations are not, presumably because of the absence of an enzyme inhibitor (such as sodium fluoride). We also note that while the $\mathrm{T}$ concentrations observed in plasma samples after spiking with TU from ethanol/PBS are stable, they are markedly lower than $\mathrm{T}$ concentrations in plasma samples spiked with TU from methanol.

More consistent results were obtained using the combination of TU prepared and spiked using methanol solutions, and measured from plasma samples. The temperature of sample preparation also appears important to obtain accurate results.

\section{Comparison of concentrations in serum \& plasma in a clinical study}

The experiments described thus far involved limited numbers of sources of samples, and thus require confirmation in a larger study. Data reported in Table 5 were obtained from a cohort of 15 subjects undergoing a clinical study of a novel formulation of TU. Table 5 presents summaries of the comparison of the PK results for $\mathrm{T}$ and DHT obtained using serum and plasma samples for each analyte. Figure 2 presents the mean analyte concentrations obtained from the serum and plasma samples.

For testosterone, results obtained from serum and plasma cannot be considered equivalent since the $\mathrm{AUC}_{0-24}$ and $\mathrm{C}_{\max 0-24}$ values are outside of the $80-125 \%$ standard equivalence acceptance range for the $90 \% \mathrm{CI}$ of the ratio (serum/plasma); the ratio was $130.02 \%$ for the $\mathrm{AUC}_{0-24}$ and $134.01 \%$ for the $\mathrm{C}_{\max 0-24}$. For DHT, although the $90 \%$ CI for the ratio (serum/plasma) for the $\mathrm{AUC}_{0-24}$ fall within the $80-125 \%$ acceptance range $(122.40 \%)$, serum and plasma cannot be considered equivalent due to significant difference between $\mathrm{C}_{\max 0-24}$ values $(130.61 \%)$.

\section{Conclusion}

During the method development of the assay for the determination of testosterone and DHT, it was observed that the ester prodrug TU and its metabolite DHTU degrade extensively to testosterone and DHT in whole blood. 
Table 4. Testosterone and phosphate buffer saline concentrations in serum or plasma harvested from blood spiked with testosterone undecanoate working solution prepared in phosphate buffer saline or methanol; spiking level 60,000 ng/dl.

\begin{tabular}{|c|c|c|c|c|c|c|c|}
\hline Experiments & $\begin{array}{l}\text { Endogenous } \\
\text { level in serum }\end{array}$ & $\begin{array}{l}\text { Endogenous } \\
\text { level in plasma }\end{array}$ & $\begin{array}{l}30 \text { min } \\
\text { serum RT }\end{array}$ & $\begin{array}{l}60 \text { min } \\
\text { serum RT }\end{array}$ & $\begin{array}{l}\text { Plasma } \\
10 \min 4^{\circ} \mathrm{C}\end{array}$ & $\begin{array}{l}\text { Plasma } \\
30 \min 4{ }^{\circ} \mathrm{C}\end{array}$ & $\begin{array}{l}\text { Plasma } \\
60 \min 4^{\circ} \mathrm{C}\end{array}$ \\
\hline \multicolumn{8}{|c|}{ Mean testosterone concentration (ng/dl) } \\
\hline $\begin{array}{l}\text { Whole blood spiked with TU } \\
\text { in PBS }\end{array}$ & 255.4 & 221.7 & 295.4 & 349.0 & 236.0 & 232.9 & 231.1 \\
\hline $\begin{array}{l}\text { Whole blood spiked with TU } \\
\text { in methanol }\end{array}$ & 255.4 & 221.7 & 854.8 & 1255.4 & 322.5 & 339.9 & 320.5 \\
\hline \multicolumn{8}{|l|}{ Mean TU concentration (ng/dl) } \\
\hline $\begin{array}{l}\text { Whole blood spiked with TU } \\
\text { in PBS }\end{array}$ & N/A & N/A & 3991.0 & 5892.3 & 74408.7 & 54088.0 & 26618.7 \\
\hline $\begin{array}{l}\text { Whole blood spiked with TU } \\
\text { in methanol }\end{array}$ & N/A & N/A & 97110.3 & 96132.3 & 97235.0 & 95628.0 & 93816.3 \\
\hline
\end{tabular}

When serum is harvested in the absence of enzyme inhibitors, the hydrolysis of TU and DHTU to T and DHT occurs during whole blood collection and processing to serum. Multiple experiments demonstrated that serum is not the preferred matrix for the analysis of T and DHT when TU is the administered medication.

During the experiments, it was demonstrated that:

- The conversion of TU to testosterone is extensive and continues over time in whole blood when no enzyme inhibitors are present;

- Even low concentrations of TU have an impact on measured testosterone concentrations;

- Temperature of collection influences the conversion rate;

- The addition of an esterase inhibitor, namely $\mathrm{NaF}$, is important to minimize the hydrolysis of TU to T.

The results of the validation of the methods in plasma $\mathrm{NaF} / \mathrm{K}_{2} \mathrm{C}_{2} \mathrm{O}_{4}$ and $\mathrm{NaF} / \mathrm{Na}_{2}$ EDTA for $\mathrm{T}$, DHT, TU and DHTU demonstrate that the assay is accurate, precise and that the analytes are stable under the conditions tested. Moreover, stability testings in presence of $\mathrm{TU}$ show that hydrolysis is minimized with $\mathrm{NaF} / \mathrm{K}_{2} \mathrm{C}_{2} \mathrm{O}_{4}$ or $\mathrm{NaF} / \mathrm{Na}_{2}$ EDTA, accompanied by low temperature sample collection.

A comparison of $\mathrm{T}$ and $\mathrm{TU}$ concentrations for serum and plasma samples spiked using either ethanol stock solutions of TU diluted into PBS or methanol stock solutions of TU diluted with methanol showed that consistent and high recoveries were only obtained using the methanol solutions and plasma samples. Whether this is a solubility or partitioning phenomena remains unclear. However, the use of PBS for the dilution of TU solution may introduce a bias in the evaluation of the impact of TU degradation on the $\mathrm{T}$ exposure.

Comparison of $\mathrm{T}$ and DHT concentrations obtained from serum and plasma samples for a clinical study demonstrates that the conversion of TU to testosterone and DHTU to DHT occurred when serum samples were collected. The observed conversion was proportional to the concentrations of TU and DHTU. The PK parameters for plasma and serum testosterone concentrations were not bioequivalent in terms of $\mathrm{C}_{\max 0-24}$ and $\mathrm{AUC}_{0-24}$. For DHT, the $\mathrm{C}_{\max 0-24}$ values were also outside the bioequivalence

Table 5. Pharmacokinetic results obtained from serum and $\mathrm{NaF}-\mathrm{Na}_{2}$ ethylenediaminetetraacetate plasma.

\begin{tabular}{|c|c|c|c|c|c|}
\hline \multirow[t]{2}{*}{ Analyte } & \multirow[t]{2}{*}{ Parameter } & \multirow[t]{2}{*}{ Ratio (\%) } & \multicolumn{2}{|c|}{$90 \%$ geometric $\mathrm{Cl}(\%)$} & \multirow[t]{2}{*}{ Intra-subject CV (\%) } \\
\hline & & & Lower & Upper & \\
\hline \multirow[t]{2}{*}{ Testosterone } & $A \cup C_{0-24}$ & 130.02 & 128.06 & 132.01 & 2.34 \\
\hline & $C_{\max 0-24}$ & 134.01 & 128.66 & 139.58 & 6.29 \\
\hline \multirow[t]{2}{*}{ Dihydrotestosterone } & $A \cup C_{0-24}$ & 122.40 & 120.33 & 124.50 & 2.63 \\
\hline & $C_{\max 0-24}$ & 130.61 & 125.38 & 136.05 & 6.30 \\
\hline
\end{tabular}




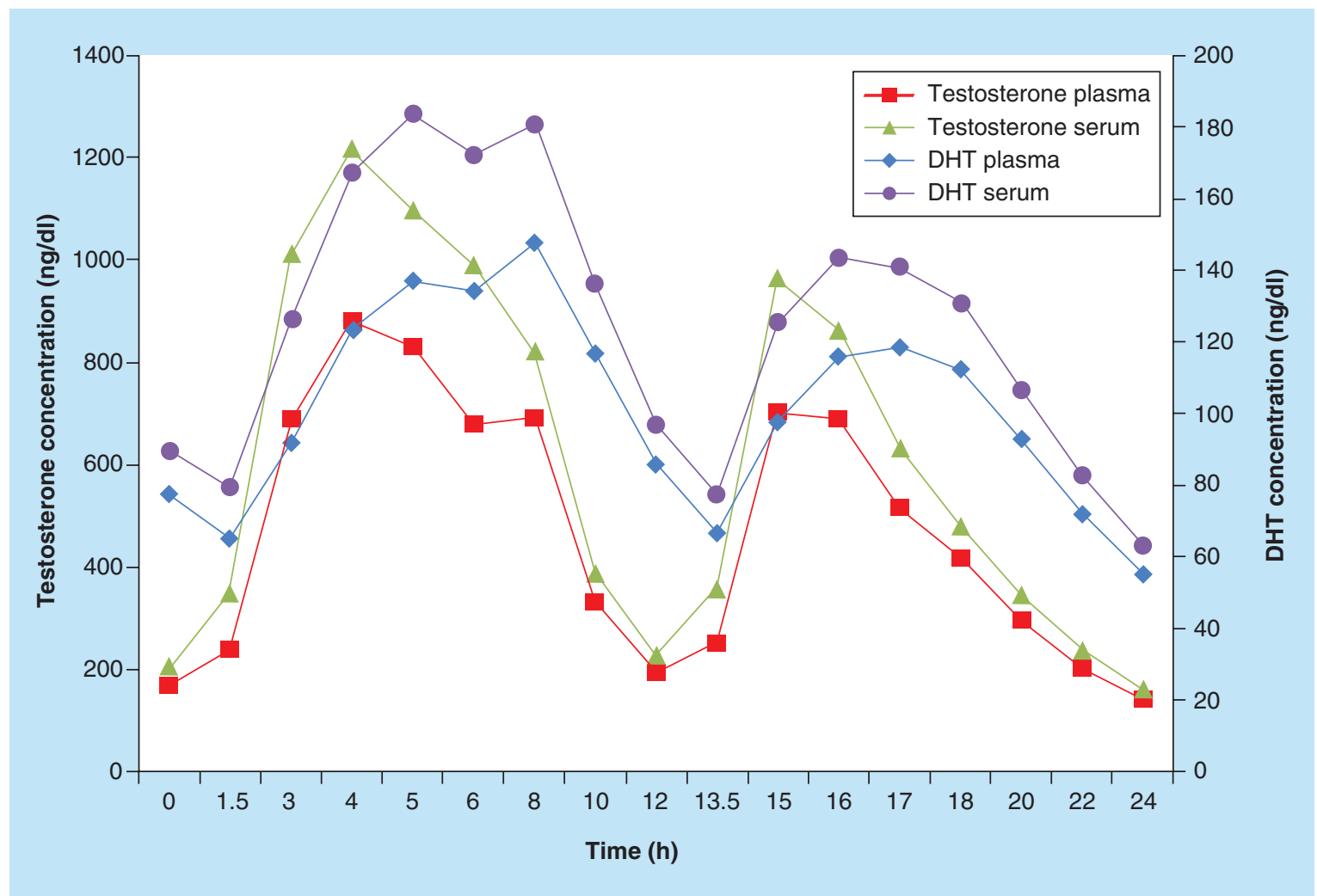

Figure 2. Testosterone and dihydrotestosterone $\mathrm{NaF} / \mathrm{Na}_{2}$ ethylenediaminetetraacetate plasma versus serum mean concentrations.

DHT: Dihydrotestosterone.

range. Results from these analyses found the day $84 \mathrm{AUC}_{0-24}$ were $29.97 \%$ higher when measured in human serum versus plasma, in a clinical study of 15 hypogonadal men administered TU twice daily for 12 weeks.

Although $\mathrm{NaF} / \mathrm{K}_{2} \mathrm{C}_{2} \mathrm{O}_{4}$ gave excellent performance in terms of preventing the hydrolysis of TU, the investigation suggests that $\mathrm{NaF} / \mathrm{Na}_{2} \mathrm{EDTA}$ is the anticoagulant of choice since the bias in testosterone level with the conventional serum tubes is slightly lower than with the $\mathrm{NaF} / \mathrm{K}_{2} \mathrm{C}_{2} \mathrm{O}_{4}$ matrix.

The observed instability of TU in serum samples would appear to render a bioanalytical method for testosterone based on serum sample analysis inappropriate due to the inaccuracy of the results obtained. It would significantly bias the decisions on the starting dose and dose adjustments during TRT as these decisions will be based on the $\mathrm{T}$ concentration that will be overestimated in serum. It is concluded that the determination of testosterone and DHT should be performed in human plasma samples obtained using $\mathrm{NaF} / \mathrm{Na}_{2}$ EDTA collection tubes.

\section{Future perspective}

The determination of testosterone has been performed in serum for many years. However, for TRT, specifically when esters of testosterone are used as prodrug, the analysis of testosterone in serum causes overestimation of testosterone exposure. This investigation demonstrates that analysis in plasma combined with an enzyme inhibitor is to be used for future bioanalytical studies.

\section{Supplementary data}

To view the supplementary data that accompany this paper please visit the journal website at: www.future-science.com/ doi/full/10.4155/FSO.15.55

\section{Author contributions}

All authors contributed equally to the publication. S Lachance, A Lévesque: scientific contribution, supervision of work, publication redaction; O Dhingra, J Bernstein: scientific contribution, publication redaction; S Gagnon, N Boudreau: scientific contribution; C Savard: scientific contribution, analytical work; N Pelletier: supervision of work, scientific contribution.

\section{Financial \& competing interests disclosure}

The authors have no relevant affiliations or financial involvement with any organization or entity with a financial interest in or financial conflict with the subject matter or materials discussed in the manuscript. This includes employ- 
ment, consultancies, honoraria, stock ownership or options, expert testimony, grants or patents received or pending, or royalties.

No writing assistance was utilized in the production of this manuscript.

\section{Ethical conduct of research}

The authors state that they have obtained appropriate institutional review board approval or have followed the prin- ciples outlined in the Declaration of Helsinki for all human or animal experimental investigations. In addition, for investigations involving human subjects, informed consent has been obtained from the participants involved.

\section{Open Access}

This work is licensed under the Creative Commons Attribution 4.0 License. To view a copy of this license, visit http://creativecommons.org/licenses/by/4.0/

\section{Executive summary}

- It was demonstrated that testosterone must be determined in plasma with sodium fluoride as enzyme inhibitor when the esters of testosterone are used as prodrug.

- Testosterone undecanoate degrades extensively into testosterone in whole blood at room temperature and without enzyme inhibitor, when serum is to be harvested.

- This degradation is time and temperature dependent.

- This was confirmed with incurred samples when serum was compared with plasma.

- Testosterone is to be determined in $\mathrm{NaF} / \mathrm{Na}_{2}$ ethylenediaminetetraacetate plasma and kept at low temperature to avoid overestimation of concentration.

\section{References}

Papers of special note have been highlighted as:

•• of considerable interest

1 Andriol (testosterone undecanoate capsules) product monograph, Merck Canada inc. Drug Product Database, Health Canada (2012). www.hc-sc.gc.ca

2 Yin AY, Htun M, Swerdloff RS et al. Re-examination of pharmacokinetics of oral testosterone undecanoate in hypogonadal men with a new self- emulsifying formulation. J. Androl. 33, 190-122 (2011).

3 Bagchus WM, Hust R, Maris F, Schnabel PG, Houwing NS. Important effect of food on the bioavailability of oral testosterone undecanoate. Pharmacotherapy 23(3), 319-325 (2003).

4 Morgentaler A, Dobs A, Kaufman J, Miner M, Shabsigh R, Swerdloff R, Wang C. Long lasting testosterone undecanoate therapy in men with hypogonadism: results of a pharmacokinetic clinical study. J. Urol. 180, 2307-2313 (2008).

5 Qoubaitary A, Meriggiola C, Ming C et al. Pharmacokinetics of testosterone undecanoate injected alone or in combination with norethisterone enanthate in healthy men. J. Androl. 27(6), 853-867 (2006).

6 Roth M, Dudley R, Hull L et al. Steady-state pharmacokinetics of oral testosterone undecanoate with concomitant inhibition of 5a-reductase by finasteride. Int. J. Androl. 34, 541-547 (2010).

7 Schnabel P, Bagchus W, Lass H, Thomsen T, Geurts P. The effect of food composition on serum testosterone levels after oral administration of Andriol ${ }^{\circledR}$ Testocaps ${ }^{\circledR}$. Clin. Endocrinol. 66, 579-585 (2007).

8 Shackleford DM, Faassen WA, Houwing $\mathrm{N}$ et al. Contribution of lymphatically trans- ported testosterone undecanoate to the systemic exposure of testosterone after oral administration of two andriol formulations in conscious lymph duct-cannulated dogs. J. Pharmacol. Exp. Ther. 306, 925-933 (2003).

9 Wang C, Shiraishi S, Leung A et al. Validation of a testosterone and dihydrotestosterone liquid chromatography tandem mass spectrometry assay: interference and comparison with established methods. Steroids 73(13), 1345-1352 (2008).

$10 \mathrm{Nq} \mathrm{BH}$, Yuen KH. Determination of plasma testosterone using a simple liquid chromatographic method. J. Chromatogr. B 793(2), 421-426, (2003).

11 Baba S, Fujioka M, Shinohara Y, Furuta T. Determination of testosterone propionate in human plasma by gas chromatography-mass spectrometry. J. Chromatogr. 337(2), 205-212, (1985).

-• Describes the established methods for testosterone measurement in androgen replacement therapy.

12 FDA. FDA backgrounder for Sept. 18, 2014 advisory committee meeting for clarus therapeutics NDA 206089, 101-104 (2014). www.fda.gov

13 EMA Guideline on Bioanalytical Method Validation February 2012 (2012). www.ema.europa.eu

- Describes the bioanalytical method validation guidelines for EMA submission.

14 Food and Drug Administration Draft Guidance for Industry. Bioanalytical method validation (2013). www.fda.gov

-. Describes the bioanalytical method validation guidelines for US FDA submission. 